\author{
A. Baisseitova ${ }^{(D)}$, O. Smailov \\ Almaty Academy of the Ministry of Internal Affairs \\ of the Republic of Kazakhstan named after Makan Esbulatov, \\ Kazakhstan, Almaty, e-mail: baliya76@mail.ru, oleqbaikz@mail.ru

\section{INTERNATIONAL EXPERIENCE IN COUNTERING TERRORISM}

The article deals with issues relating to international cooperation in countering terrorism and using the positive experience of foreign countries in ensuring security.

Terrorism and extremism are estimated by the authors as the main threats not only to national, but also to international security. Recognizing the global nature of these threats, the international community seeks to develop a common policy of struggle, since the effectiveness of anti-terrorism measures can only be achieved with active interstate cooperation.

Currently, at the level of the United Nations, a number of conventions and protocols have been adopted, aimed at unifying legal concepts in the sphere of countering terrorism and extremism, creating unified mechanisms for preventing and suppressing crimes of a terrorist nature. The paper analyzes the main provisions of these international conventions and evaluates their importance for ensuring security throughout the world.

Considering that the Republic of Kazakhstan has not so great practical experience in countering terrorism, the issues of researching legislation and practice of the law enforcement agencies of foreign countries that have been fighting for many years against terrorism and extremism are of particular relevance. The authors, analyzing the modern legal framework and the practice of joint activities of the competent authorities of various states in countering terrorism, justify their proposals for the further development of international cooperation in this field. The study of foreign experience, its systematization, adaptation to the conditions of Kazakhstan will help optimize the activities against terrorism and extremism and avoid possible mistakes in the choice of means and methods of such a struggle.

Key words: terrorism, extremism, international experience, international cooperation, countering terrorism, national security.

\author{
А.Т. Байсеитова, Ө.Х. Смаилов \\ Қазақстан Республикасы IIM Мақан Есболатов атындағы Алматы академиясы, \\ Қазақстан, Алматы қ., e-mail: baliya76@mail.ru, oleqbaikz@mail.ru
}

Ааңкестікке қарсы іс-қимылдың халықаралық тәжірибесі

Мақалада лаңкестікке қарсы іс-қимы^ саласындағы халықаралық ынтымақтастыққа және шетел мемлекеттерінің қауіпсіздігін қамтамасыз етудегі оң тәжірибесін қолданылуына қатысты мәселелер қарастырылады.

Терроризм мен экстремизмді авторлар ұлттық қауіпсіздікке ғана емес, халықаралық, қауіпсіздіктің негізгі қауіп-қатерлері ретінде бағалайды. Осы қауіптердің жаһандық сипатын мойындай отырып, халықаралық қоғамдастық терроризмге қарсы жалпы саясатты әзірлеуге тырысады, өйткені маңкестікке қарсы шаралардың тиімділігі тек белсенді мемлекетаралық ынтымақтастықпен қамтамасыз етіледі. Қазіргі уақытта Біріккен Ұлттар Ұйымының деңгейінде лаңкестікке және экстремизмге қарсы тұру саласындағы құқықтық ұғымдарды бірыңғай түсіндіруге, террористік сипаттағы қылмыстардың алдын алу және жолын кесудің жалпы механизмлерін құруға бағытталған бірқатар конвенциялар мен хаттамалар қабылданды. Мақалада авторлар осы халықаралық конвенциялардың негізгі ережелерін талдайды және олардың бүкіл әлемдегі қауіпсіздікті қамтамасыз ету үшін маңыздылығын бағалайды.

Қазақстан Республикасы терроризмге қарсы күресте үлкен тәжірибесі жоқ екенін ескере отырып, көптеген жылдар бойы лаңкестік пен экстремизмге қарсы күресті жүзеге асырып жатқан шет мемлекеттердің заңнамасы мен құқық қорғау органдарының мен тәжірибесін зерделеу мәселелері ерекше мәнге ие. Терроризмге қарсы іс-қимы^да әртүрлі мемлекеттердің іс жүзіндегі нормативтік құқықтық базасын және құзыретті органдарының практикалық тәжірибесін талдап отырған авторлар осы саладағы халықаралық ынтымақтастықты одан әрі дамыту бойынша өз ұсыныстарын негіздейді. Шетелдік тәжірибені зерделеу, оны жүйелендіру, Қазақстанның 
жағдайына бейімделу маңкестік пен экстремизмге қарсы іс-әрекеттерді оңтайландыруға және мұндай күрестің құра^дары мен әдістерін таңдауда ықтимал қателіктерді болдырмауға көмектесеАі.

Түйін сөздер: лаңкестік, экстремизм, халықаралық, тәжірибе, халықаралық, ынтымақтастық, лаңкестікке қарсы іс-қимыл, ұлттық қауіпсіздік.

\section{А.Т. Байсеитова, О.Х. Смаилов}

Алматинская академия МВА Республики Казахстан имени Макана Есбулатова, Казахстан, г. Алматы, e-mail: baliya76@mail.ru, oleqbaikz@mail.ru

\section{Международный опыт противодействия терроризму}

В статье рассматриваются вопросы, касающиеся международного сотрудничества при противодействии терроризму и использования положительного опыта зарубежных стран по обеспечению безопасности.

Терроризм и экстремизм оцениваются авторами как основные угрозы не только национальной, но и межАународной безопасности. Признавая глобальный характер этих угроз, межАународное сообщество стремится выработать еАиную политику противодействия, поскольку эффективность антитеррористических мер возможно обеспечить только при активном межгосударственном сотрудничестве. В настоящее время на уровне Организации Объединенных Наций принят ряд конвенций и протоколов к ним, направленных на унификацию правовых понятий в сфере противодействия терроризму и экстремизму, создание еАиных механизмов преАупреждения и пресечения преступлений террористической направленности. В работе проводится ана^из основных положений данных международных конвенций, оценивается их значение Аля обеспечения безопасности во всем мире.

Учитывая, что Республика Казахстан имеет не столь большой практический опыт в деле противодействия терроризму, особую актуальность приобретают вопросы исследования законодательства и практики деятельности правоохранительных органов зарубежных государств, которые ведут многолетнюю борьбу с терроризмом и экстремизмом. Авторы, анализируя современную правовую базу и практику совместной деятельности компетентных органов размичных государств по противодействию терроризму, обосновывают свои предложения по Аальнейшему развитию международного сотрудничества в Аанной сфере. Изучение зарубежного опыта, его систематизация, адаптация к условиям Казахстана позволят оптимизировать деятельность по борьбе с терроризмом и экстремизмом и избежать возможных ошибок в выборе средств и методов такой борьбы.

Кмючевые слова: терроризм, экстремизм, международный опыт, международное сотрудничество, противодействие терроризму, национальная безопасность.

\section{Introduction}

The events of the last decade associated with the increased terrorist activities of various extremist organizations of political, religious and other orientation determine the relevance of the preparation of effective government activities to prevent terrorist and extremist crimes in Kazakhstan.

After the terrorist attacks in New York and Washington (USA) in September 2001, terrorism and extremism have began to be considered as the global security threats. Despite its role on international area none of the countries in the world is able to prevent the actions of terrorists alone. The terrorists have proved once again that they are a real threat from who no nation in the world is secured. Neither the most sophisticated state government, nor a developed economy, nor the internal cohesion of society, nor the presence of a powerful, well- equipped state law enforcement agencies can resist the unpredictable, cruel and inhumane tactics of terrorists.

In the modern world, extremism and terrorism have not only outgrown the framework of national borders and acquired a global scale, but also continuously evolve, acquiring all new types, forms and methods, powerful structures with a certain ideology, corresponding material and technical base (infrastructure) as well as financial economic opportunities.

The examples of countries in the Middle East, North Africa, and Turkey show that terrorism can not only frighten, but also wage targeted wars, as well as participate in interstate and mixed conflicts.

Obviously, in such a situation, the effective fight against terrorism as an extraterritorial phenomenon must be comprehensive, combining efforts at all levels: universal, regional and domestic. Measures taken only at the national level will have a limited 
effect. To ensure their own security, each state needs international cooperation.

\section{Research methods}

The problem of countering international terrorism requires the use of various research methods. This is a dialectic method of cognition of objectively existing phenomena and processes, methods of analysis and synthesis, statistical, comparative legal, historical and logical methods. Such a strictly scientific methodological approach allows the use of various tools and methods of perception and cognition to determine the characteristics of the studied phenomena, justifying their causality and interdependence.

The purpose of the work determines the dominance of some of the above methods. Thus, the use of a formal legal analysis allowed the author to conduct a rigorous study of the regulatory legal acts of Kazakhstan relating to the problems of countering terrorism and extremism.

On the basis of using the method of comparative legal analysis, the necessity of studying and introducing the positive experience of foreign countries and the further development of international cooperation in this field has been substantiated. In addition, this method allows you to compare the approach to the definition of terrorism and extremism in various legislative acts of the Republic of Kazakhstan, to identify existing legal conflicts and propose specific measures to eliminate them.

\section{Results}

1. International standards in the field of countering terrorism.

The first international experience in the fight against terrorism was the International Conference on the fight against anarchists, held in NovemberDecember 1898 in Rome. The conference was attended by 21 countries, including Russia, France, the United Kingdom, the United States and others. The main objective of this conference was to establish a permanent agreement between European governments in the interests of public protection in order to successfully counter anarchist communities and their followers. During the conference of 1898 , the concept of "terrorism" was not yet in place; therefore, they used the term "anarchy". In particular, the conference discussed the issue of the difficulty of defining an anarchic crime, but the indisputable sign of anarchism remained - the goal of violating the state or social system (Ausharip, 2006). In the late 60 s of the last century, reports of hijacking aircraft, bombings in embassies, abduction of diplomats, provocations and direct attacks on various government and non-government agencies, as well as the use of postal communication to send plastic letters-bombs began to appear more often.

In such circumstances, the question of combating terrorist acts within the framework of the international community of states was sharply raised. In this regard, in his note of September 8, 1972 (A/ 8791), the UN Secretary-General requested that the agenda of the XXVII session of the UN General Assembly should include an item entitled "Measures aimed at preventing terrorism and other forms of violence that threaten the lives of innocent people either lead to their death, or endanger the fundamental freedoms" (Zhilin 2002).

At a plenary meeting held on September 23, 1972, the UN General Assembly recommended that this item be put on the agenda and referred to the Sixth Committee for consideration in the following modified wording: "Measures to prevent international terrorism that threatens the lives of innocent people or leads to their death or endangering fundamental freedoms, and exploring the root causes of these forms of terrorism and acts of violence stemming from poverty, despair, misfortune and despair and encouraging some people to sacrifice human s lives, including their own, in an effort to achieve radical change" (Kostenko, 2002). Of particular importance in the document under review is a provision to encourage the continuation of the study of the possibility of establishing an International Criminal Court, which would have jurisdiction over the persons who committed international terrorist acts.

On December 18, 1972, the General Assembly, on the recommendation of the Sixth Committee, adopted Resolution 3034 (XXVII), in accordance with paragraph 9 of which the Ad Hoc Committee on International Terrorism was established. The Committee included Algeria, Hungary, Great Britain, Yemen, USSR, USA, Syria, Tunisia, the Ukrainian SSR, the Czech Republic, France, Yugoslavia, Japan, etc.

Thus, the term "international terrorism", appearing first on the pages of the world press, was enshrined in UN documents.

At one time, the League of Nations also attempted to work out a convention to combat terrorist acts of an international character. The need for this convention was caused by the wave of terrorist acts after the First World War (https://www. wdl.org/ru/item/11579/). 
On November 16, 1937, the Convention on the Prevention and Punishment of Terrorism, prepared by the Committee of Experts, was opened for signature in Geneva. The Convention defined acts of terrorism as actions directed against any state, the purpose and nature of which is to sow fear among individuals, groups or the population. Despite the fact that this Convention developed a number of progressive provisions, in particular, determined the nature of a terrorist act as international by virtue of the object of attack; the functional basis for providing the persons concerned with protection against the crimes provided for in Art. 2 and 3 of the Convention; the principle of inevitability of punishment is ensured; indicated the need for cooperation between States in connection with the application of the Convention; the guarantee of the fulfillment of its provisions through the adoption of relevant legislation is provided; the Convention could not become universal due to the existence of the right to a "colonial reservation". The colonial reservation means that the states parties to the Convention, when signing, ratifying or acceding to the Convention, could declare that its action does not fully or partially extend to colonies, mandated and other dependent territories. Equally, the states parties to the Convention could exercise this right even during the Convention's period (UN General Assembly 2001).

The practice of the League of Nations and the United Nations has taken the path of elaborating conventions separating the terrorist activities of individuals from the policy of terror pursued by states and providing protection against terrorist acts of an international character by virtue of certain functions of a person or a special status of property in relation to which a terrorist act was committed. The protection of international law against the commission of terrorist acts of an international character currently includes: aircraft crews and air lines, both internal and external, by virtue of the conclusion of the Hague and Montreal conventions for the fight against unlawful interference with civil aviation; persons and their residential and official premises, in respect of which the host state must provide special protection by virtue of the functions assigned to these persons on behalf of their state or international (intergovernmental) organization in the service of which they are composed.

After the terrorist attacks of September 11, 2001 in the United States, the United Nations was particularly active in creating mechanisms for the international legal regulation of the fight against terrorism. Thus, the UN General Assembly considered the question of these tragic events the very day after the attack and unanimously adopted a resolution in which it called for international cooperation to prevent and eradicate acts of terrorism and bring to justice the perpetrators, organizers and sponsors of acts of violence. On the same day, the Security Council in its resolution 1368 (2001) called on the international community to redouble its efforts to prevent and suppress terrorist acts, including by increasing cooperation and ensuring the full implementation of relevant international antiterrorist conventions and Security Council resolutions, in particular 1269 (1999).

The most important event in the antiterrorist cooperation of states was the resumption of the activities of the Special Committee established in accordance with General Assembly resolution $51 / 210$ of December 17, 1996, with the aim of elaborating a Comprehensive Convention on International Terrorism. Thanks to the work of the aforementioned Special Committee, on September 28, 2001, the Security Council unanimously adopted Resolution 1373 on combating international terrorism. This document provides a wide range of concrete measures at the national, regional and international levels aimed at combating terrorism (Security Council Resolution 1373, 2001).

The modern system of multilateral cooperation in the fight against terrorism as a whole has developed mainly in the last half century under the auspices of the UN. It is based on universal conventions and protocols relating to the fight against various manifestations of terrorism and extremism: the Convention on Offenses and Certain Other Acts Committed on Aircraft (Tokyo, 1963), the Convention on the Suppression of Unlawful Seizure of Aircraft (The Hague, 1970 d), Convention for the Suppression of Unlawful Acts against the Safety of Civil Aviation (Montreal, 1971), International Convention against the Taking of Hostages (New York, 1979), International Convention for the Suppression of Bombings, Terrorism om (New York, 1997), International Convention for the Suppression of the Financing of Terrorism (New York, 1999), International Convention for the Suppression of Acts of Nuclear Terrorism (New York, 2005) and others.

These multilateral agreements are the immediate legal acts governing the fight against the international form of terrorism. These international legal acts do not apply if terrorism is committed within and in violation of the interests of one state and does not give rise to international relations. 
Currently, the Republic of Kazakhstan has acceded to almost all major conventions relating to terrorism. Accession to such documents requires a review of the legislation of the Republic of Kazakhstan concerning the issue regulated in the international act, analysis of possible situations on this issue in the case of accession to the international act from the perspective of Kazakhstan's interests. Therefore, the process of accession to international conventions is carried out gradually, but still at a fairly fast pace.

The fight against international terrorism at the level of international agreements does not stop at the $\mathrm{UN}$ conventions and protocols to them.

Currently, the implementation of effective international cooperation in countering manifestations of terrorism and extremism is associated with the prospects for the scientific development of the problem of terrorism and extremism, their forms and manifestations, allowing them to be considered as independent social phenomena. These are threats to international, collective and national security. Accordingly, it is possible to distinguish three levels of normative regulation of activities to counter terrorism and extremism - international, regional and national.

The Republic of Kazakhstan is a party to a number of relevant regional conventions and treaties. In particular, Kazakhstan is a party of the Shanghai Convention on Combating Terrorism, Separatism and Extremism, as well as a number of fundamental interstate regulations with the CIS member states.

In accordance with the Program of Cooperation of the CIS Member States in the early 2000s, work on the progress in harmonizing the legal framework for countering traditional threats was analyzed, new challenges and threats to security were systematized, and directions for their regulatory prevention were identified. The materials obtained served as the methodological basis for improving the model legislative anti-terrorism base in accordance with international legal norms. Today we can say that the antiterrorist model legislation of the CIS has been modernized, structured and supplemented, has acquired the character of a detailed and, most importantly, mutually agreed set of standards.

The founding documents of the interstate cooperation of the internal affairs bodies on the problem under discussion are the Treaty on Cooperation of the Member States of the Commonwealth of Independent States in the Fight Against Terrorism and the Program of Cooperation of the CIS Member States in the Fight Against Terrorism and Other Violent Displays of Extremism.
In particular, the Program of cooperation of the CIS member states in the fight against terrorism and other violent manifestations of extremism for 2005-2007, 2008-2010, 2011-2013 and 2014-2016, 2017-2020.

The basis of the cooperation of the CIS countries in the fight against terrorism and extremism lies in the accumulated practice based on established traditions. The interaction of the power ministries is carried out in a combination of multilateral and bilateral bases that complement and enrich each other. It is they who allow them to solve the tasks of combating terrorism in a comprehensive and largescale manner.

The increase of the level of information support had a positive impact on the final results of countering terrorism. The intensification of joint measures for the search and detention of persons involved in terrorist activities is being considered. In order to increase the efficiency of practical interaction, joint operational groups are created if necessary. There are many examples of the detention of people wanted at the intergovernmental level. Information exchange on legal entities, individuals and organizations involved in terrorist and extremist activities and their financing has intensified. Intensive interchange of invalid passport databases.

Similarly, other countries are creating regional legal mechanisms that facilitate cooperation in preventing and combating terrorism. However, in the overwhelming majority of cases, the primary responsibility for developing and implementing legal instruments for the prevention and punishment of crimes related to terrorism and extremism lies with the states themselves, which adopt their own legislation. Despite the participation of states in international agreements, their domestic legal measures differ significantly from each other. In other words, in accordance with the level of legal regulation of counteraction, international terrorism and domestic terrorism can be distinguished.

2. The study of the experience of countering terrorism in foreign countries.

The Republic of Kazakhstan is at the epicenter of terrorist and extremist threats, therefore it is appropriate to consider the conceptual legal norms developed by the world community in the fight against terrorist actions, since they have proven their effectiveness in countering terrorism and extremism.

In this area, it is important to find the most interesting, and most importantly, one that has proven its approach in the sphere of regulating the fight against terrorism and extremism in the traditional legal systems of such countries as Israel.

In Israel, the fight against terrorism is carried 
out by the security service, the army, the police, the foreign ministry and the prison administration. There is no Constitution in the state of Israel, but the basic norms of the law that determine the rights of a person and a citizen have a hierarchy of constitutional laws. In Israel, terrorism is the intention or threat to use violence against civilians and civilian objects to achieve political goals or change political course. In Israel, among the traditional methods of struggle known to us, there is such an approach as the pinpoint destruction of terrorists. Spot destruction - one of the main methods of combating terrorists. Despite the condemnation of the world community, in Israel this method is used in practice. Accurate destruction is carried out without a judicial act being issued; upon completion of the operation, the military prosecutor's office checks the legality of the decision. It should be noted that this measure is applied in exceptional cases when there are no other possibilities to destroy terrorists (Zhakayev, 2015).

In Israel the special services involved in the fight against terrorism, a common conceptual terminology is used, which ensures the consistency of counterterrorism measures. There are regular explanatory conversations on the goals of individual terrorist organizations, lectures on security issues with specific examples from the past and their thorough analysis, general lines of behavior of students, teachers and public servants are worked out. It is also important to point out the financial monitoring system in Israel that ensures the effectiveness of countering the financing of religious terrorism. The information system about the accountable persons (registered as extremist or terrorist movement supporters) has been put into effect, which is integrated with the operating systems of financial monitoring entities (Lexis-Nexis program) and provides immediate information on financial transactions, allowing to suspend financial transactions more before transferring funds (Kulagin, 2009).

Apart from Israel, such countries as Argentina, Colombia, Jordan, Turkey, and Uruguay are taking an extremely tough stance towards terrorists. Governments and other countries are inclined to refuse to meet the demands of terrorists. In many countries of Europe and Latin America, sanctions are taken against those firms that insure their employees in case of kidnapping by terrorists and agree to buy back the captured or stolen representatives.

Many countries, adhering to the concept of "no concessions to terrorists," tend to use more flexible tactics in dealing with terrorists. They believe that the most effective method of resolving conflict situations is negotiating, especially if several states are involved. According to the leaders of these countries, negotiations with terrorists are necessary in order to secure the release of at least some of the hostages (women, children, the sick). Negotiations give the official authorities a number of advantages and can contribute to the peaceful outcome of the incident. This position is supported by countries such as: France, England, USA and Holland. Practice shows that this method of solving the problem provides a favorable resolution of terrorist incidents. Its use in practice saved many lives of hostages (Ustinov, 2002).

Some countries, when choosing a course of action in the context of an act of terrorism, proceed from the nationality of its participants. This principle is explained by the fact that if the citizens of the country on whose territory the terrorist act is committed are taken hostage, they are released immediately. If the hostages are foreigners, the local authorities are coordinated with the governments of the countries of which they are citizens. This view is held, in particular, by Belgium.

Given the heightened threat of terrorism, which has a detrimental effect on peace and stability, the issues of organizing effective counteraction have become a key point of international interaction between different countries. Modern terrorism requires the development of new conceptual approaches, since the existing counter-terrorism algorithm shows its inability to ensure calm in society. States of different countries are worried about the situation in society among the population, which explains the large number of regulatory documents with which the state carries out the fight against terrorism and extremism.

Thus, in most Western countries, the specificity of the legal regulation of crimes related to extremism and terrorism lies in its preventive orientation and the avoidance of the most serious consequences of these crimes. In this regard, the main emphasis is on punishment for inciting hatred against ethnic and religious groups. In a number of Western countries, such crimes and offenses are classified as hate crime - "hate crimes", including hate speech - "hostile speech", and provide for criminal and / or civil liability. The need to separate these crimes into a separate category is due to their socially dangerous nature: in addition to harming individuals (groups of individuals), they are directed against society and the state as a whole and may entail more serious consequences if they turn (which often happened) into a terrorist activities. 


\section{Conclusion}

Despite the fact that the Republic of Kazakhstan is a politically stable state, it is necessary to pay special attention to foreign and international experience in combating international terrorism. Lack of personal experience entails unpreparedness for sudden international terrorist acts due to their unpredictability. In addition, law enforcement agencies need knowledge of world experience in the prevention of international terrorism, since the prevention of socially dangerous phenomena must be carried out when there is still no potential danger. This is also due to the fact that the prevention of international terrorism consists in solving social and economic problems in the state, the right course of foreign and domestic policy, a consensual solution of interstate, interethnic and religious problems. For this, it is necessary to use the practice of combating international terrorism in other countries, and, therefore, possess information, systematize, analyze and adapt to the conditions of Kazakhstan.

For these purposes, the National Security Committee, the General Prosecutor's Office, the Ministry of the Interior and the Ministry of Foreign Affairs have established a single data bank on terrorism and other manifestations of extremism and separatism on the basis of the relevant interdepartmental regulatory act to coordinate actions against terrorism at the domestic and interstate levels. The exchange of such information at the interstate level, as well as direct cooperation in the main areas of operational and anti-terrorism activities, is carried out on the basis of international obligations.

World experience in combating international terrorism has determined the paramount importance of combating the financing of terrorism and organized crime, which have identified the main areas of activity of law enforcement agencies of the Republic of Kazakhstan.

Domestic legal methods of combating terrorism are significantly different from the legal regulation of Western, especially European countries. On the one hand, Kazakhstan is a party to the overwhelming number of international and regional agreements on countering terrorism and extremism and enshrines them in national legislation. The choice of the legal form of application of foreign experience depends on the political will of the state itself (Agybayev 2018).On the other hand, Kazakh legislation proper concentrates mainly on prohibitive measures. Legislative and judicial practice reflects the general trend of tougher penalties for crimes of a terrorist and extremist nature. Enforcement also demonstrates gaps in the implementation of laws designed to prevent discrimination, the conscientious implementation of which helps prevent the emergence of terrorist and extremist groups and reduces the need for harsh criminal penalties. Despite the presence of a rather broad domestic legislative base and the already existing bias towards harsh measures, at present there is an even greater tightening of responsibility for crimes related to terrorism and extremism.

\section{References}

Ausharip G. Pravovyye problemy uchastiya Kazakhstana v mezhgosudarstvennom sotrudnichestve po bor'be s mezhdunarodnym terrorizmom [Legal problems of Kazakhstan's participation in interstate cooperation in the fight against international terrorism]: dis. ... Cand. legal sciences. Almaty, 2006. P.19 (In Russian).

Agybayev A., Adibayeva A. Implementing mechanisms of the un convention on genocide in the criminal legislation of the participating states: general comparative analysis. News of The National Academy of Sciences of The Republic of Kazakhstan. Series of Social and Human Sciences. ISSN 2224-5294. https://doi.org/10.32014/2018. 2224-5294.6. Volume 5, Number 321 (2018), 39 - 43.

Baysagatova D.B. Rol' Respubliki Kazakhstan v protivodeystvii mezhdunarodnomu terrorizmu i ekstremizmu [The role of the Republic of Kazakhstan in countering international terrorism and extremism] // Bulletin of the Institute of Legislation of the Republic of Kazakhstan. 2015. No 4 (40). P. 183-187. (In Russian).

Kostenko N. Teoreticheskiye problemy stanovleniya i razvitiya mezhdunarodnoy ugolovnoy yustitsii [Theoretical problems of the formation and development of international criminal justice]: dis. ... Dr. legal sciences. M, 2002. P. 51. (In Russian).

Kulagin M.A. K voprosu o mezhdunarodnom vzaimodeystvii v protivodeystvii terrorizmu v usloviyakh globalizatsii [To the question of the international interaction in counteraction terrorism in the conditions of globalization] // Yurist"-pravoved". 2009. No 5. P.29. (In Russian).

Measures to prevent international terrorism that threatens the lives of innocent people, or leads to their death, or endangers fundamental freedoms, and studying the root causes of these forms of terrorism and acts of violence, resulting from poverty, despair, 
misfortune and despair and causing some people to sacrifice human lives, including their own, in striving for radical change: Study prepared by the Secretariat in accordance with the decision taken by the Sixth Committee at its 1314th meeting, September 27, 1972 years (A/ C. 6/418).

Convention for the Prevention and Punishment of Terrorism, 1937 // https://www.wdl.org/ru/item/11579/

Security Council Resolution 1373 (2001). September 28, 2001 [on threats to international peace and security caused by terrorist acts].

Ustinov V.V. Mezhdunarodnyy opyt bor'by s terrorizmom: standarty i praktika [International experience in the fight against terrorism: standards and practices]. M.: Yurlitinform, 2002. 560 p. (In Russian).

UN General Assembly. Official reports: 56 session. New York: UN, 2001. 32 p.

Zhilin Yu. Globalizatsiya v kontekste razvitiya sovremennoy tsivilizatsi [Globalization in the context of the development of modern civilization] // Free Thought. 2002. No 4. P. 3-7. (In Russian).

Zhakayev B., Nurgazinov B. Blizhnevostochnyy opyt protivodeystviya terrorizmu [Middle Eastern Experience in Countering Terrorism] // Law and Time. 2015. No 8. P. 43-48. (In Russian). 